\title{
Relationships between subclinical laminitis and sole ulcer in cows
}

\author{
P. Mudron̆ \\ pavol.mudron@uvlf.sk \\ University of Veterinary Medicine and Pharmacy in Košice, clinic of ruminants, \\ 73 Komenského, Košice, 04181, Slovakia
}

\begin{abstract}
Subclinical laminitis is a multifactorial syndrome with complex pathophysiology and significant economic impact on dairy industry. One of the effects it has on the welfare of cattle is that it predisposes to the development of other lesions on the foot, predominantly sole ulcers and white line disease. The aim of the study was to investigate if the subclinical laminitis actually predisposes dairy cows to the development of sole ulcer. The data used in this study were obtained on 220 Holstein Friesian dairy cows during of routine orthopedic and claw trimming visits as well as within a period between them when lame cows were treated. All of the cows were kept on manure solid bedding and fed TMR. The average milk year yield was $9000 \mathrm{~kg}$. At the first visit the cows with subclinical laminitis were identified (LS group). The occurrence of the sole ulcer was checked at the following visits in all the cows. Out of the 220 examined dairy cows, 10 were affected by the subclinical laminitis (LS group; $4.55 \%$ ). 69 dairy cows were free of claw diseases (control group; $31.4 \%)$. In the following orthopaedic controls, the sole ulcer was detected in two cows from the LS group (20\%) and only in one cow in the control group (1.45\%). The difference in incidence of the sole ulcer between both groups was significant $(P<0.05)$. The results of this study indicate that there is an association between subclinical laminitis and prevalence of sole ulcer in dairy cows.
\end{abstract}

Key words: cows, subclinical laminitis, sole ulcer

Lameness is the most serious welfare problem facing the dairy cow and the European dairy industry. The disorder causes pain and distress for the cow and substantial economic losses. When evaluating the cost of each case of lameness, many factors have to be considered, which can be divided into direct and indirect costs. Indirect losses are related to: prolonged calving interval, culling losses, reduced milk yield, weight loss and replacement costs. The direct losses are considered to be the veterinary expenses and drugs. A quarter of all losses of lameness, are due to the reduced milk yield and the discarded antibiotic-treated milk during the therapy periods. Cows with a higher yield have an increased risk of lameness, and problems with lameness occur primarily in the early lactation period; one to three months [7].

Lameness is a multifactorial condition. Primary causes include infectious agents (e.g., foot rot, digital dermatitis), laminitis, conformational or other lesions (e.g., corkscrew claw, leg injury); and claw lesions such as white line disease, thin sole-induced toe ulcers, sole ulcers, toe ulcers, sole punctures, and thin soles [2]. Sole ulcers, which are one of the most severe pathologies causing lameness, are non-infectious in nature and occur when claw horn formation is disrupted. The underlying tissue then becomes inflamed and sometimes exposed. Cows are particularly vulnerable around the time of parturition; changes in hormone levels cause increased vascular permeability, increasing the risk of oedema and ischemia in the hoof [5].

The purpose of this study was to examine the relationship between body condition score and claw diseases in dairy cows in order to form a better understanding of the development of claw diseases.

\section{Materials and Methods}

The data used in this study were obtained on 220 Holstein Friesian dairy cows during two sessions of routine orthopaedic and claw trimming visits (autumn 2016 and spring 2017) as well as within a period between them when lame cows were treated. All of the cows were kept on manure solid bedding and fed TMR. The average milk year yield was $9000 \mathrm{~kg}$. At the first visit the cows with subclinical laminitis were identified (LS group). The diagnosis of the subclinical laminitis was based on an observation of symptoms of sole haemorrhages and yellowish-coloured soles. The occurrence of the sole ulcer was checked at the following visits in all the cows. Statistical analysis was performed by running a chi-squared test to test a difference between sole ulcer incidence in LS and control (healthy) group. 


\section{Results and Discussion}

Out of the 220 dairy cows examined during autumn 2016 ten cows were affected by the subclinical laminitis (LS group; $4.55 \%$ ). 69 dairy cows were free of claw diseases (control group; $31.4 \%$ ). In the following orthopaedic controls the sole ulcer was detected in two cows from the LS group (20\%) and only in one cow in the control group (1.45\%). The difference in incidence of the sole ulcer between both groups was significant $(P<0.05$, table $)$.

Laminitis is an inflammation of the laminar corium of the hoof wall. In general, the term laminitis is used to describe a systemic disease affecting not only the hooves, but also the general condition of the animal. Researchers believe the inflammation is primarily associated with a dysfunction of the digital vasculatory system that results in hypoxia and malnutrition of the sensitive laminar structure in the hoof wall. The aetiology of the circulatory disturbance is not fully understood and there are some possible explanations often related to nutrition, which we will discuss further. Due to mechanical stretching of the attachment between the inner and outer laminar structures of the hoof wall, which has been affected by the inflammation (i.e. laminitis), the claw bone can rotate and or sink inside the hoof [1]. Depending on the severity of the laminitis, the mobility of the claw bone inside the capsule and the counter pressure on the sole from hard floors, the sole corium can be contused and secondary lesions of the sole area can develop [6].

Subclinical laminitis is a multi-factorial welfare issue which predisposes to the development of other sole lesions, such as sole ulcer and white line disease, by weakening the integrity of claw tissues. Its impact on the economy of dairy industries is enormous, with up to $52 \%$ (average 20-25\%) of high-production intensively-managed dairy cows becoming lame each year [4].

Sole ulcers are one of the most common causes of lameness in dairy cows and the most important one [8]. Over the last few years, an extensive change has been in the supposed role of nutritional management in the control of lameness. In the past, the control of subacute ruminal acidosis (SARA) was believed to be a major factor in limiting claw horn lesions because of SARA's suggested role in the development of laminitis [3]. The control of SARA is still believed to be important for maintaining the health and production but it has now been proven to be of low priority in the control of lameness.

In our study $20 \%$ of cows suffering from subclinical laminitis during the controls ended up developing sole ulcer on either the same or different claw. Although the number of patients tested is relatively reduced, the results of the study are significant and justify the hypothesis of the relationship between subclinical laminitis and sole ulcer. As above mentioned, laminitis is a disease of many aetiologies and have such a complex pathogenesis, that some mechanisms may predispose to the development of sole ulcer at a certain time and another time not. It is vital to keep in mind that not only disease or infection leads to sole lesions, but welfare, nutrition, management and different stages of the life of the animal play a crucial role on the emergence of lesions on the claws that cause lameness and reduce productivity.
Table. Assessment of the sole ulcer in 220 dairy cows (100\%) with/without subclinical laminitis

\begin{tabular}{l|c|c|c|c}
\hline \multirow{2}{*}{ Claw Status } & \multicolumn{2}{|c|}{$1^{\text {st }}$ trimming } & \multicolumn{2}{c}{$\begin{array}{c}\text { Sole ulcer } \\
\text { on subsequent trimmings }\end{array}$} \\
\cline { 2 - 5 } & $\mathrm{N}$ & $\%$ & $\mathrm{~N}$ & $\%$ \\
\hline No Disorders & 69 & 31.4 & 1 & 1.45 (of 69) \\
\hline Subclinical Laminitis & 10 & 4.55 & 2 & 20 (of 10) \\
\hline
\end{tabular}

Note. ${ }^{*}-\mathrm{P}<0.05, x^{2}$-test.

\section{Conclusion}

The results of this study indicate that there is an association between subclinical laminitis and prevalence of sole ulcer in dairy cows. Therefore, a dairy farm management should pay more attention to avoid all known risk for subclinical laminitis development on the farm to prevent higher incidence of lameness.

\section{Prospects for Further Research}

Laminitis is a complicated disease of which the origin is not clearly understood. Overall, the update information strongly suggests that endotoxins (ET) play a significant role in the development of laminitis in dairy cows. It is important to continue expanding our knowledge of ET and to develop possible preventative measures against their actions on the host. Although more information is available for the role of lipopolysaccharides, several studies indicate a contribution of lipoteichoic acid in this disorder as well, which demonstrates a need to also increase research efforts in this area.

1. Bergsten C. Causes, risk factors, and prevention of laminitis and related claw lesions. Acta Veterinaria Scandinavica. 2003; 44(1): S157. DOI: 10.1186/1751-0147-44-S1-S157.

2. Cook NB, Nordlund KV. The influence of the environment on dairy behavior, claw health and herd lameness dynamics. Vet Journal. 2009; 179(3): 360-369. DOI: 10.1016/j.tvjl.2007.09.016.

3. Danscher AM, Toelboell TH, Wattle O. Biomechanics and histology of bovine claw suspensory tissue in early acute laminitis. Journal of Dairy Science. 2010; 93(1): 53-62. DOI: 10.3168/ jds.2009-2038.

4. Green LE, Hedges VJ, Schukken YH, Blowey RW, Packington AJ. The impact of clinical lameness on the milk yield of dairy cows. Journal of Dairy Science. 2002; 85(9): 2250-2256. DOI: 10.3168/ jds.S0022-0302(02)74304-X.

5. Knott L, Tarlton JF, Craft H, Webster AJF. Effects of housing, parturition and diet change on the biochemistry and biomechanics of the support structures of the hoof of dairy heifers. The Veterinary Journal. 2007; 174(2): 277-287. DOI: 10.1016/j.tvjl.2006.09.007.

6. Ossent $P$, Lisher $C$. Bovine laminitis: the lesions and their pathogenesis. In Practice. 1998; 20: 415-427. DOI: 10.1136/inpract.20.8.415.

7. Peake KA, Biggs AM, Argo CM, Smith RF, Christley RM, Routly JE, Dobson $\mathrm{H}$. Effects of lameness, subclinical mastitis and loss of body condition on reproductive performance of dairy cows. Vet. Record. 2011; 168(11): 301-306. DOI: 10.1136/vr.c6180.

8. Van Amstel SR, Shearer JK. Review of Pododermatitis circumscripta (ulceration of the sole) in dairy cows. Journal of Veterinary Internal Medicine. 2006; 20(4): 805-811. DOI: 10.1111/ j.1939-1676.2006.tb01789.x. 


\section{3в'язок між субклінічним ламінітом та виразкою підошви у корів}

\section{П. Мудрон}

pavol.mudron@uvlf.sk

Університет ветеринарної медицини та фармації у Кошице, клініка жуйних тварин,

Вул. Коменського, 73, м. Кошице, 04181, Словаччина

Субклінічний ламініт — це багатофракторний синдром зі складною патофізіологією та значним економічним впливом на молочне скотарство. Один із негативних наслідків ламініту на здоров'я великої рогатої худоби полягає в можливому ускладненні його перебігу іншими хворобами копит, зокрема виразкою підошви та патологіями білої лінії. Метою нашого дослідження було з'ясування ролі субклінічного ламініту у розвитку виразки підошви. Використані у цьому дослідженні дані були отримані на 220 молочних голштинофризьских коровах під час планових сеансів ортопедичного огляду та обрізання копит, а також при лікуванні захворювань копит. Корів утримували на глибокій підстилці і годували повнораціонною кормовою сумішшю (TMR). Середня річна молочна продуктивність корів становила 9000 кг. При першому відвідуванні виявляли корів з субклінічним ламінітом. При наступних обстеженнях всіх корів перевіряли на наявність виразки підошви. 3220 обстежених молочних корів, у 10-ти діагностовано субклінічний ламініт (дослідна група; 4,55 \%), а у 69 корів не виявлено жодних патологій копит (контрольна група; 31,4 \%). Під час наступних обстежень виразка підошви була виявлена двох корів із групи з субклінічним ламінітом (20 \%) та лише у однієї корови контрольної групи $(1,45 \%)$. Різниця захворюваності на виразку підошви між групами була статистично вірогідною $(P<0,05)$. Результати цього дослідження свідчать про взаємозв'язок між наявністю субклінічного ламініту та виникненням виразки підошви у корів.

Ключові слова: корови, субклінічний ламініт, виразка підошви 